\title{
Assertive Speech Acts in Donald Trump's Presidential Speeches
}

\author{
Kartika Dina Ashfira, Tofan Dwi Harjanto* \\ English Department, Universitas Gadjah Mada, Indonesia \\ *Corresponding Author: deha@ugm.ac.id
}

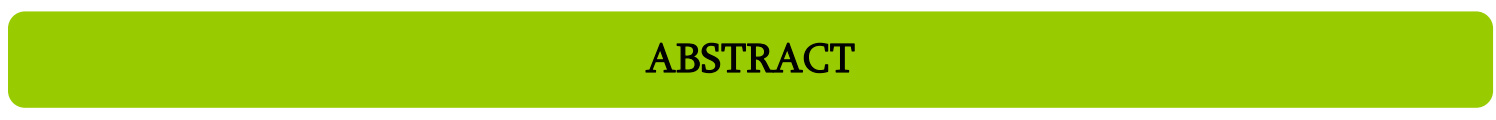

\begin{abstract}
This research investigates assertive speech acts in Donald Trump's presidential speeches. It classifies the assertive speech acts based on their illocutionary forces according to Bach and Harnish (1979). The data were taken from three speeches by Donald Trump. The results show that the illocutionary forces of assertive speech acts found in the speeches are affirming, alleging, asserting, avowing, claiming, declaring, denying, maintaining, propounding, saying, and stating. The act of stating is the most commonly used (44\%). The findings suggest that Trump uses the act of stating mostly because he wants the hearer to believe him that the policies he has made are the best for the United States.
\end{abstract}

Keywords: assertive speech acts, Donald Trump, illocutionary forces, political speech.

\section{INTRODUCTION}

As the $45^{\text {th }}$ US President, Donald Trump is quite different from his predecessors. One simple difference is about political background. Former US presidents mostly have had experiences in politics before becoming a president, for example Franklin Roosevelt, John F. Kennedy, Bill Clinton, George Bush, Barrack Obama, and many more. Donald Trump is the only US president who never works in government office as he was once a businessman.

Another difference is about the policies he makes. During his presidency, Trump has made changes to several policies which were referred being controversial by big news agencies, for instance Al Jazeera, Euronews, and Washington Post. An Al Jazeera correspondent pointed out that the border policies were controversial and they have caused humanitarian crisis as many families were separated (Zhou-Castro, 2019, para.1). Then,
Euronews (2019) states that Trump, on the State of Union Address, has repeated controversial policies as he said that he needed a Southern border wall, banning late-term abortion, and bringing American troops home from Syria (para. 1-2). At last, FischerBaum and Vitkovskaya (2018) added that Trump's administration has made changes to U.S policies in which some of them reversed Obama's signature agreement, for example travel ban, Iran nuclear deal, Paris agreement, Mexico border wall, Cuba, and so on (para. 1). These policies, in fact, have raised people's criticism towards Trump's policies which are believed to harm a particular group of people.

There have been some pragmatic studies which investigates political speeches, for instance Hardjanto and Mazia (2018) investigated epistemic modality in Justin Trudeau's presidential speeches; Khoirunnisa (2015) investigates illocutionary acts in Soekarno's 1995 Asian-African Conference; Akinwotu (2013) investigated illocutionary acts 
verbs in Nomination Speech of Chief Obafemi Awalowo and Chief M. K. O. Abiola; and Lazuka (2003) investigated communicative intention in George W. Bush's presidential speeches from 20012003. Nevertheless, the studies about Donald Trump's presidential speeches are still rare compared to other US presidents. Thus, the present study attempts to fill the gap by analyzing a more specific illocutionary act, namely assertive speech acts in Donald Trump's presidential speeches. More specifically, it aims to examine what assertive speech acts Donald Trump used in his speeches and classify the assertive speech acts that Donald Trump used according to their illocutionary forces.

\section{LITERATURE REVIEW}

There have been numerous pragmatic studies on presidential speeches (Akinwotu, 2013; Alattar, 2014; Hashim, 2015; Khoirunnisa, 2016; Lazuka, 2006; Mufiah \& Rahman, 2018). Akinwotu (2013) examines the usage of illocutionary act verbs of the acceptance of nomination speeches of presidential candidates in Nigeria. By applying Searle's speech act theory $(1969 ; 1976)$, the most used speech acts by the two presidential candidates were assertive speech acts. The illocutionary force of assertive speech acts found in the nomination speeches were stating, suggesting, describing, claiming, and informing. It was concluded that acceptance of nomination speeches mostly used assertive speech acts because it was used as mobilization strategies especially in political campaign in persuading the people to choose the candidate.

Alattar (2014) investigates speech acts in the American presidential speeches of Ronald Reagan, Bill Clinton, George W. Bush, and Barrack Obama. It aims at analyzing presidential speeches to reveal political purpose of their speeches by applying Bach and Harnish's (1979) taxonomy of illocutionary act as a theoretical framework. The result showed that a speech delivered by Ronald Reagan, after Space Shuttle Challenger tragedy had happened, was dominated by acknowledgement speech acts (50\%), followed by assertive speech acts (30\%). In Bill Clinton's speech, to form a belief to people to see the change in him in account of his inappropriate relationship with Monica Lewinsky, assertive speech acts were found the most (38,9\%). Meanwhile, informative speech acts were frequently used in George W. Bush's speech, with the amount of $64,4 \%$ as he wanted to inform people why U.S was going to war with Iraq. Then in Barrack Obama's speech, advisory speech acts were used the most, with the amount of $48,05 \%$ because the speech was managed as a motivational speech for students. All in all, socio-political events experienced by the country held significance in choosing the types of speech acts being uttered by presidents in their presidential speeches.

Hashim (2015) examined speech acts in John Kerry's political speeches in presidential campaign in 2004 and George W. Bush's Inaugural Address in 2001. He attempted to identify speech acts featured in the speeches, analyze the features in relation to the contexts, and examine how the features show the message in the speeches. The findings, which were based on speech acts theory by Austin (1962) and Searle (1969), showed that Kerry's speech used commissive speech acts the most while Bush used assertive speech acts the most. Kerry used commissive to commit himself to some future action and Bush used assertive to assert his authority.

Studies on political speeches have also been investigated by Indonesians. Khoirunnisa (2015) studied illocutionary acts found in Soekarno's speech in the 1955 Asian-African Conference. She analyzed Soekarno's speech by using Searle's (1969) taxonomy of illocutionary acts and applying the theory of English Illocutionary Verbs by Searle and Vanderveken (1985). The result showed that the most frequently used of illocutionary acts is assertive (stating), because the speech aimed to convince the audience to believe that Asian-African nations could be united under the shared past experience of being colonized.

Lazuka (2006) studied communicative intentions in George W. Bush's presidential speeches and statements from September 2001 until September 2003 by applying Bach and Harnish's taxonomy of illocutionary acts (1979). She also investigated the discourse by using Scollon and Scollon's (2000) theory of anticipatory discourse. The findings suggested that in reference to US authorities Bush used informative speech acts the 
most before the war when referring to the positive actions of government or Bush himself. Meanwhile in reference to the audience or the hearer, Bush used assertive speech acts the most to propagate and preserve America's positive self-perception. On the other hand, in reference with enemy Bush used assertive speech acts which contain a negative portrayal of the enemy. In brief, Bush's selection of speech acts depended on his communicative intention. In the speeches, Bush attempted to present the authorities in a positive way to preserve the United States' legitimacy whilst portraying the enemy in a negative way.

Mufiah and Rahman (2018) examined speech acts analysis of Donald Trump's Inaugural Speech in 2017. By using Yule's (1996) speech acts classification, the researchers found out that representative speech acts were used the most by Trump in his Inaugural Speech. Representatives were found 29 out of 63 data, which account the number of $46 \%$. To sum up, representative speech acts were intended as statement of fact and assertion to assert to the people about what will happen of the nation in the future.

There have been many studies about speech act analysis of presidential speeches. Yet, speech acts analysis about Trump's presidential speeches is still rare compared to other US presidents. Hence, this research tried to fill the gap by investigating Donald Trump's presidential speeches.

\section{THEORETICAL FRAMEWORK}

\section{Speech Acts}

Speech Acts theory was firstly introduced by Austin in 1955. Austin (1962) states that in saying something we perform three different things, locutionary act, illocutionary act, and perlocutionary act (pp. 108-109). Locutionary Act is a speech act when someone says an utterance. Illocutionary Act is when a speaker utters an utterance, he has an intended action behind his utterance. Perlocutionary Act is the effect of an utterance uttered by a speaker. In this act, the hearer is expected to perform something after hearing what the speaker has uttered. Therefore, this distinction is very important as it sorts out the utterance someone says.

Bach (2006) gives an example of performing speech acts by providing an example, "The bar will be closed in five minutes,". In saying the utterance, the bartender is performing the locutionary act of saying the bar (i.e., the one he is tending) will be closed in five minutes (from the time of utterance). Then, the bartender is also performing the illocutionary act of informing the patrons of the bar's imminent closing (and perhaps also the act of urging them to order a last drink). In the end, the bartender intends to be performing perlocutionary acts (utterance which produces further effects) of causing the patrons to believe that the bar is about to close and of getting them to order one last drink. $\mathrm{He}$ is performing all these speech acts, at all three levels, just by uttering certain words (p. 50).

\section{Speech Acts Classification}

An attempt was made in classifying speech acts into five classes by Austin since firstly introduced in 1955. These speech acts were later developed into seven classes by Vendler (1972). However, Austin's classification was criticized by Searle (1976), who ended up creating his own classification of speech acts in 1976. Following Searle's five classes of speech acts (1976), Bach and Harnish (1979) and Allan (1986) made an attempt in classifying the speech acts classes as well.

Austin (1962) classified performative verbs into five general classes. They are verdictives, exercitives, commissives, behabitives, and expositives. Verdictives are the giving of a verdict by a jury, arbitrator, or umpire, e.g. sentencing, pleading, pronouncing, etc. Exercitives are the exercising of powers, right, or influence, e.g. appointing, voting, ordering, urging, advising, warning, etc. Commissives are committing you to do something, including declarations or announcements of intention, e.g. promising, announcing, opening, declaring, etc. Behabitives have to do with attitudes and social behavior, e.g. apologizing, congratulating, commending, condoling, cursing, and challenging. Expositives are making plain how our utterances fit into the course of arguments or conversations, e.g. 'I reply', 'I 
argue', 'I illustrate', 'I assume', 'I postulate' (pp. 150151).

As mentioned above, Austin's (1962) classification of speech acts was criticized by Searle (1976) who rejected the distinction of the five classes and pointed out some weakness. As Mey (2001, p. 117) points out:

"Searle criticizes Austin for operating with overlapping criteria, for having incompatible elements within his categories, for including elements in his categories that do not satisfy the definition of the category, and so on. But mainly, Searle is unhappy about the fact that Austin apparently does not pay attention to the difference between speech acts and speech act verbs; the existence or no-existence of the latter cannot be a criterion for the existence and no-existence of a particular speech act."

\section{Searle's Taxonomy of Illocutionary Acts}

After finding Austin's weakness on his taxonomy of speech acts, Searle (1976) divides speech acts into five categories. Allan (1986) added that Searle differentiates speech acts by using their illocutionary point (the intention of the speech act), direction of fit (the way speech acts fit the world), expressed psychological state (speaker's state of mind), and propositional content (what the speech act is about/related to felicity conditions) (p. 191). The categories of speech acts that Searle (1976) proposes are as follows.

\section{a) Representative}

The representative speech act commits the speaker to something's being the case, to the truth of the expressed proposition. The direction of fit is words-to-world where the speaker represents fitting the state of affairs in the world. E.g. : state, affirm, remind, assert, and so on.

\section{b) Directive}

The directive speech act makes the speaker attempts the hearer to do something. The direction of fit is world-to-word which is to get the world match with propositional content and success of fit lies on the hearer. E.g. : ask, order, command, request, beg, plead, pray, entreat, invite, permit, advise, dare, defy, challenge.

\section{c) Commissive}

The commissive speech act commits the speaker to some future course of action. The direction of fit is world-to-word as it gets the world to match the propositional content and the achieving success of fit lies on the speaker. E.g. : promise, commit, threaten, vow, pledge, swear, accept, refuse, bid, offer, assure, guarantee, bet, etc

\section{d) Expressive}

The expressive speech act expresses the psychological state of the speaker. It has no direction of fit as the speaker is neither trying to get the world to match the words nor the words to match the world. It only expresses the speaker's attitude about their psychological state. E.g. : thank, congratulate, apologize, condole, deplore, welcome.

\section{e) Declarative}

The declarative speech act effects immediate changes in some current state of affairs. The speaker brings about changes in the world. The direction of fit is both world-to-words and words-to-world (null direction of fit) because the speaker makes the world match the propositional content by saying the propositional content matches the world. E,g, : declare, resign, appoint, approve, confirm, nominate, disapprove, etc.

\section{Bach and Harnish's Taxonomy of Illocutionary Acts}

Bach and Harnish (1979) points out that "types of illocutionary acts are distinguished by types of illocutionary intents (intended illocutionary effects). Since illocutionary intents are fulfilled if the hearer recognizes the attitudes expressed by the speaker, types of illocutionary intents correspond to types of expressed attitudes. Accordingly, we will classify types of illocutionary acts in terms of types of expressed attitudes." (p. 39).

Allan (1986) argues that Bach and Harnish employed all of Searle's criteria except direction of fit within their taxonomy of illocutionary acts. They emphasized to speaker's psychological state - which is referred as speaker's 'attitude' - then illocutionary intention, making it clear that these are partially determined on the basis of utterance's propositional content (p. 191). 
Speech Act Schema or SAS, in Bach and Harnish (1979), represents the general form of illocutionary intention and inference, and the entries in the taxonomy. The purpose of SAS is identifying the illocutionary act being performed. Such acts can be identified from their intents (hearer's recognition of speaker's expressed attitude). So the distinguishing features of illocutionary acts type have to specify the thing the hearer must identify.

Bach and Harnish (1979) divided the illocutionary acts into six general categories. Two of the categories, effectives and verdictives, are not communicative, but conventional. The other four are communicative illocutionary acts. They are constatives, directives, commissives, and acknowledgements. Four of these "correspond roughly to Austin's expositives, exercitives, commissives, and behabitives, respectively and closely to Searle's representatives, directives, commissives, and expressive although the characterizations of them are different from Searle's" (Bach \& Harnish, 1979, pp. 40-41).

\section{a) Constatives}

Constatives express the speaker's belief and has an intention that the hearer form (or continue to hold) a like belief. Subcategories which includes in this class are assertives, predictive, retrodictives, descriptives, ascriptives, informatives, confirmatives, concessives, retractives, assentives, dissentives, disputatives, responsives, suggestives, suppositives.

b) Directives

Directives express the speaker's attitude towards an action and become reason for the hearer's action. Bach and Harnish (1979) stated that they had borrowed Searle's term "directive" for this class. Directives cover six kinds of acts, requestives, questions, requirements, prohibitives, permissives, and advisories.

\section{c) Commissives}

Commissives are acts of obligating oneself to do the intention and the belief that one's utterance commits one to do it, under the conditions specified. Commissives cover the subcategories of promises and offers. d) Acknowledgements

Acknowledgements correspond roughly to Austin's class of "behabitives". Acknowledgements express certain feelings toward the hearer. Example of its performative verbs are apologize, condole, greet, thank, bid, etc.

\section{Assertives}

Assertives belong to the constative category. As constatives are the expression of a belief and having the intention that the hearer form a like belief, the assertives also have an effect to the hearer believes what the speaker utters. Felicity conditions for assertives are in uttering $e$ (an expression (typically a sentence), $S$ (the speaker) asserts that $P$ (the propositional content of the illocutionary act) if $S$ expresses the belief that $P$ and the intention that $H$ (the hearer) believe that $P$. Performative verbs for this subcategories are affirm, allege, assert, aver, avow, claim, declare, deny (assert...not), indicate, maintain, propound, say, state, and submit.

The assertives have different strength of belief expressed and in the corresponding expressed intention. "When one maintains, or avows something, one's expressed belief and intention are very strong, whereas the belief and intention expressed when one alleges or submits that something is the case are much weaker," (Bach \& Harnish, 1979, pp. 44-45).

Bach and Harnish's (1979) taxonomy was used in analyzing assertive speech acts in Trump's presidential speeches because this taxonomy covers a great many type of illocutionary acts in detail and not only labeling but also specifying what distinguishes them.

\section{METHODS}

\section{Data Source}

The data sources used in this research were Donald Trump's presidential speeches. Three speeches were selected: a) Statement by President on the Paris Climate Accord (2,878 words), b) Remarks by 
President Trump on The Policy of the United States Towards Cuba (3,205 words), and c) Remarks by President Trump on the National Security and Humanitarian Crisis on the Southern Border (3,836 words). These speeches were chosen because they represented Trump's policies, which were referred as 'controversial' by big news agencies such as $\mathrm{Al}$ Jazeera, Euronews, and The Washington Post. The videos of the speeches were obtained from Youtube. In addition, the scripts of the speeches were also consulted. They were obtained from The White House official website.

\section{Method of Data Collection}

The primary data were Trump's speeches (from the video) which were supported by the video transcripts. There were speeches which had a Q \& A sessions, hence the session was omitted focusing only on Trump's utterances. The data were Trump's utterances containing assertive speech acts. These assertive speech acts were identified on the basis of the felicity conditions of assertive speech acts as shown below.

Table 1. Felicity conditions for Assertives (modified from Allan, 1998)

\begin{tabular}{|l|l|}
\hline description & $\begin{array}{l}\text { In uttering } \mathrm{U}, \mathrm{S} \text { asserts } \\
\text { that } p \text { if } \mathrm{S} \text { expresses }\end{array}$ \\
\hline precondition & the belief that $p$ and \\
\hline $\begin{array}{l}\text { illocutionary } \\
\text { intention }\end{array}$ & $\begin{array}{l}\text { the intention that } \mathrm{H} \\
\text { believe that } p\end{array}$ \\
\hline
\end{tabular}

We collected the assertive speech acts by doing the following steps. First, watching and downloading Trump's speeches from Youtube. After downloading the transcripts from White House official website, we checked whether the speeches' videos synchronized with the transcripts or not. Then, identifying the assertive speech acts in the transcripts by applying criteria of felicity conditions of assertive speech acts by Bach and Harnish (1979). After that, highlighting the assertive speech acts found in the three speeches.

\section{Method of Data Analysis}

After all the data were collected, they were analyzed and classified according to Bach and
Harnish's (1979) assertive speech acts. Then the assertive speech acts found were displayed in a table and description. On top of that, the data were analyzed quantitatively by finding the frequency. After that, describing the table by discussing and analyzing the assertive speech acts according to their illocutionary forces.

The assertive speech acts were coded according to the titles of the speeches, the categories of assertive speech acts, and the number of occurrences. The code PCA was used for Paris Climate Agreement, PUSTC for Policy of the United States Towards Cuba, and HCOSB for Humanitarian Crisis on the Southern Border. The illocutionary force of assertive speech acts were coded as AF for affirming, AL for alleging, AS for asserting, AVO for avowing, CL for claiming, DC for declaring, DN for denying, MA for maintaining, PR for propounding, SY for saying, and ST for stating.

The example below illustrates the coding system used in this research.

(1) Therefore, in order to fulfill my solemn duty to protect America and its citizens, the United States will withdraw from the Paris Climate Accord - (applause) - thank you, thank you - but begin negotiations to reenter either the Paris Accord or a really entirely new transaction on terms that are fair to the United States, its businesses, its workers, its people, its taxpayers. (PCA.DC.01)

In the example above, the code PCA stands for Paris Climate Agreement, the title of the speech. Then DC stands for declaring, one of the illocutionary forces of assertive speech acts, and 01 stands for the first occurrence of the assertive speech act of declaring found in the speeches.

\section{RESULTS AND DISCUSSION}

\section{Types of Assertive Speech Acts}

A total of 152 assertive speech acts were found in Trump's presidential speeches. 42 were found in Paris Climate Agreement, 50 in Policy United States towards Cuba, and 60 in Humanitarian Crisis on 
Southern Border. These assertive speech acts were classified based on their illocutionary forces.

Table 2. Frequency of Assertive Speech Acts

\begin{tabular}{|l|l|r|r|}
\hline No. & \multicolumn{1}{|c|}{$\begin{array}{c}\text { Illocutionary } \\
\text { Force }\end{array}$} & Frequency & \multicolumn{1}{c|}{$\%$} \\
\hline 1. & Affirming & 5 & 3.2 \\
\hline 2. & Alleging & 18 & 13.8 \\
\hline 3. & Asserting & - & 11.8 \\
\hline 4. & Averring & 5 & 3.2 \\
\hline 5. & Avowing & 16 & 10.5 \\
\hline 6. & Claiming & 3 & 1.9 \\
\hline 7. & Declaring & 5 & 3.2 \\
\hline 8. & $\begin{array}{l}\text { Denying } \\
\text { assert... not })\end{array}$ & - & - \\
\hline 9. & Indicating & 4 & 2.6 \\
\hline 10. & Maintaining & 1 & 0.6 \\
\hline 11. & Propounding & 7 & 4.6 \\
\hline 12. & Saying & 67 & 44.0 \\
\hline 13 & Stating & - & - \\
\hline 14. & Submitting & 152 & 100 \\
\hline & & Total & \\
\hline
\end{tabular}

Table 2 above shows that the most frequently used assertive speech act was the speech act of stating with 67 occurrences (44\%), followed by alleging with 21 occurrences (13,8\%), asserting with 18 occurrences $(11,8 \%)$ and claiming with 16 occurrences $(10,5 \%)$. The other assertive speech acts were used less frequently (fewer than 10 occurrences). These include the speech act of saying with 7 occurrences (4,6\%), affirming with 5 occurrences $(3,2 \%)$, avowing with 5 occurrences $(3,2 \%)$, denying with 5 occurrences $(3,2 \%)$, and maintaining with 4 occurrences (2,6\%). The illocutionary force of declaring were used 3 times $(1,9 \%)$ and propounding only once $(0,6 \%)$. The speech acts of averring, indicating, and submitting were not used at all.

These findings seem to indicate that Trump uses the illocutionary force of stating the most because he wants to make the hearers feel informed and believe the statements being uttered. In this context, he is eager to convey messages to the hearer that the policies he has made are the best for the United States. Stating has preparatory condition of a fact or truth which makes Trump has uttered an utterance based on facts that he knows, so he wants to tell the hearers what he believes. This finding supports Khoirunnisa (2015) who found that assertive (stating) is the most commonly used speech act in Soekarno's speech in the 1955 AsianAfrican Conference.

\section{Affirming}

Leech (1983, p. 223) points out that affirm is a confident assertion. According to Collins Online Dictionary, affirm (n.d.) is to say positively; declare firmly; assert to be true or to make valid; confirm; uphold; ratify (a law, decision, or judgment). On the speeches, Donald Trump produces five utterances which imply illocutionary force of affirming. Below are the two examples.

(2) Therefore, in order to fulfill my solemn duty to protect America and its citizens, the United States will withdraw from the Paris Climate Accord - (applause) - thank you, thank you - but begin negotiations to reenter either the Paris Accord or a really entirely new transaction on terms that are fair to the United States, its businesses, its workers, its people, its taxpayers. So we're getting out. (PCA.AF.01)

(3) America has rejected the Cuban people's oppressors. They are rejected. Officially today, they are rejected. (PUSTC.AF.05)

The utterance in example (2) shows that it has an illocutionary force of affirming. The act of affirming is said implicitly because the utterance does not contain a performative verb. The function of affirming is to asserting confidently to the hearer that the United States is going to withdraw from the Paris Agreement because in the previous statement Trump has declared that the United States will withdraw from the agreement. The act of affirming is indicated by a conjunction 'so', which marks the utterance concludes what has been uttered earlier. Therefore, it can be said that the utterance has an intention in stating and confirming Trump's decision of the United States' withdrawal from the agreement.

In example (3), even though the utterance does not have any performative verb of affirm, but it implies that Trump expresses an act of affirming. 
In the previous statement, Trump refers to the Cuban government as Cuban people's oppressors because the US-Cuba deal only benefits the Cuban government, not the Cuban people. As a result, Trump repeats firmly that starting from that day the Cuban government is officially rejected by the United States. An act of affirming also can be seen from the preposition of time 'today', followed by an adverb of 'officially' which emphasizes that the Cuban government are finally and officially rejected by the United States. So, it can be concluded that the utterance has the intention to affirm.

\section{Alleging}

According to Collins Online Dictionary, allege (n.d.) is to assert positively, or declare; esp., to assert without proof. Trump uses the act of alleging quite a lot, with 21 utterances found, marking it as the second most commonly used of illocutionary act. Most of the utterances are found in positive sentences while only three utterances are found in negative sentences.

(4) The Castro regime has shipped arms to North Korea and fueled chaos in Venezuela. While imprisoning innocents, it has harbored cop killers, hijackers, and terrorists. It has supported human trafficking, forced labor, and exploitation all around the globe. (PCA.AL.13-14)

(5) And I want to thank law enforcement, and I want to thank Border Patrol, and I want to thank ICE. ICE is abused by the press and by the Democrats. (HCOSB.AL.20)

In examples (4) and (5), Trump uses positive sentences to express the act of alleging. Trump is saying and accusing the Cuban government in (4) of fueling chaos in Venezuela, employing terrorists, and supporting the human trafficking, forced labor, and exploitation. Then in (7), Trump thinks that the press and the Democrats party has attacked the ICE (Immigration and Customs Enforcement), but without giving any trusted proof.

(6) In short, the agreement doesn't eliminate coal jobs, it just transfers those jobs out of America and the United States, and ships them to foreign countries. (PCA.AL.03)
(7) The Paris Agreement handicaps the United States economy in order to win praise from the very foreign capitals and global activists that have long sought to gain wealth at our country's expense. They don't put America first. (PCA.AL.07)

In examples (6) and (7), Trump uses negative sentences to express an act of alleging. There are no performative verbs found in the utterances yet they imply the intention of alleging. It can be seen from the utterances that based on Trump's knowledge in example (6), Trump alleges the Paris Agreement not eliminating coal power plants because he thinks that the agreement only prohibits the United States' coal power plants but it allows other countries of building coal power plants. Meanwhile Trump also asserts in example (7) that the Paris Agreement not putting the America first because he thinks the agreement benefits other countries more than the United States itself. So it can be inferred that Trump implies the act of alleging by stating the utterances based on his knowledge without giving any credible proof.

By using the act of alleging, Trump has created bad portrayal of particular groups, namely Paris Agreement, the Cuban government, the US press, and the Democrats party without any proof. This kind of portrayal has been confirmed by Lazuka (2006) in which the findings discovered that the speaker presented the authorities in a positive way while portrayed the enemy in a negative way. Therefore, the utterances in the example (4), (5), (6), and (7) have the intention of alleging.

\section{Asserting}

According to Collins Online Dictionary, assert (n.d.) is to state positively; declare; affirm or to maintain or defend (rights, claims, etc). The act of asserting is the third most frequently used subtype of assertive speech acts in the three speeches with 18 occurrences.

(8) But the bottom line is that the Paris Accord is very unfair, at the highest level, to the United States. (PCA.AS.01)

(9) So this says, "strengthening the policy of the United States towards Cuba." And I can add, "strengthening a lot.". So this is very 
important, and you watch what's going to happen. (PUSTC.AS.13)

In example (8) the intention of asserting can be found. Asserting such expression, Trump states to the hearer that the Paris Agreement has been very unfair to the United States because this agreement has led to the US' harsh economy restriction. The act of asserting can be identified from the adverb which comes before the used verbs. For instance, in example (8) Trump uses an adverb 'very' to emphasize the utterance that the Paris Agreement is not fair at all to the United States.

Then, in example (9), Trump implicitly uses the act of asserting. Asserting on this utterance has an intention to states firmly and refers to the previous sentence, which says that the letter Trump has been signed says "strengthening the policy of the United States towards Cuba". The sentence plays such an important role in the US-Cuba deal that Trump asserts it as "very important". In example (9), Trump uses an adverb of "very" too before the adjective 'important' to highlight the utterance as something important in higher degree. According to Collins Online Dictionary, very (n.d.) can be used to give emphasis to an adjective or adverb. Thus, the existence of adverb 'very' can help pointing out the act of asserting.

(10) I said, "Let me ask you, as a crowd: When the wall went up, was it better?" You were there, some of you. It was not only better; it was like 100 percent better. (HCOSB.AS.17)

(11) What do we do? We set up blue ribbon committees. Lovely men and women - they sit around a table, they have lunch, they eat, they dine, and they waste a lot of time. So if we want to get smart, we can get smart. You can end the drug problem. You can end it a lot faster than you think. (HCOSB.AS.20)

Similarly, in examples (10) and (11), the intention of asserting can also be found. The intention in example (10) is to put a stress that border walls in the US-Mexico border should be built in order to prevent more illegal immigrants coming to the United States. The assertion can be seen from Trump's utterance which uses a comparative degree "better" in emphasizing the intention. Then, the utterance of "You can end it a lost faster than you think" in example (11) expresses an illocutionary force of asserting as well. Though there is no performative verb of asserting, it implicitly implies the act of asserting. On this utterance, Trump has the intention to state that the drug problem can be stopped and assert that it can be solved a lot faster. The act of asserting is emphasized by the comparative degree "faster". So it can be concluded that the utterance above implies an intention of asserting, because there is an adjective preceded by comparative degree which indicates the act of asserting. It actually confirms what is indicated by Cohen and Krifka (2014) that "Since superlative quantifiers are illocutionary operators..." (p.58), in which the findings show that superlative quantifiers have significance in the speech acts.

\section{Avowing}

According to Collins Online Dictionary, avow (n.d.) is to declare openly or admit frankly or to acknowledge or claim (oneself) to be. Bach and Harnish (1979) stated that when one maintains or avows something, one's expressed belief and intention are very strong (pp. 44-45). So, it means that the degree strength of avowing is stronger than other acts such as asserting or stating. The act of avowing has occurred five times in the three speeches. The act of avowing can be found in examples below.

(12) As someone who cares deeply about the environment, which I do, I cannot in good conscience support a deal that punishes the United States - which is what it does -- the world's leader in environmental protection, while imposing no meaningful obligations on the world's leading polluters. (PCA.AVO.01)

(13) We will very strongly restrict American dollars flowing to the military, security, and intelligence services that are the core of Castro regime. (PUSTC.AVO.03)

(14) So we're going to confront the national security crisis on our southern border. And we're going to do it one way or the other we have to do it - not because it was a campaign promise, which it is. (HCOSB.AVO.05) 
In expressing the act of avowing, Trump tends to use auxiliary verbs such as can, will, going to, and have to. In example (12), there is no performative verb of avowing, but the act of avowing can be emphasized by the auxiliary verb 'can'. The act of avowing in example (12) has an intention to assert that Trump is not be able to support a deal which does not benefit the United States. The word in good conscience' stresses that Trump, as a president, will not bring any harm to the United States.

In example (13), Trump expresses the act of avowing by using auxiliary verb 'will' followed by adverb 'very' and 'strongly' which make the utterance have high degree of strength and show the commitment being made. Thus, by uttering example (13) Trump tries to state strongly that the United States is going to restrict the business between the US-Cuba in order that money from the business will not fall into the wrong side, or in this context fall into the Cuban government.

Additionally, in example (14) Trump expresses the act of avowing by using auxiliary verb 'be going to' and 'have to' which also show the commitment of future act. This utterance in example (14) has an intention to asserting that the United States needs to confront the national security crisis on the Southern border. This utterance is based on the truth value of previous sentences that instead of controlling the United States' own border, the United States is fighting wars that are 6,000 miles away from the United States. So, Trump avows that the United States is going to secure its own border.

\section{Claiming}

According to Collins Online Dictionary, claim (n.d.) is to state as a fact or as one's belief (something that may be called into question). On the other hand, Leech (1983) indicates that claim "may be called argumentative, since they express the relation between the current truth claim and other truth claims made by $\mathrm{S}$ or $\mathrm{H}$. In an argument, each participant may be said to have a 'position', which is the set of logically interrelated beliefs which the participant is concerned to justify and defend. Thus the verb claim 'lays claim to' a given proposition as belonging to, or supporting, S's position.” (p.224).
Utterances which contain illocutionary force of claiming have occurred 16 times.

(15) And exiting the agreement protects the United States from future intrusions on the United States' sovereignty and massive future legal liability. (PCA.CL.04)

(16) My action today bypasses the military and the government, to help the Cuban people themselves form business and pursue much better lives. (PUSTC.CL.05)

\section{(17) Walls work 100 percent. (HCOSB.CL.09)}

Although there are no performative verbs of claiming, the utterances found above implicitly imply an illocutionary force of claiming. In example (15), Trump states that by quitting the Paris Agreement, the United States will be protected from future intrusions and legal liability. In fact, what he meant with future intrusions and legal liability is a limit into manufacturers sector. According to World Resource Institute, the United States is the world's second largest emitter and in 2013 responsible for $13,7 \%$ of greenhouse gas (GHG) emissions, including land-use change and forestry (Urpelainen and Van de Graaf, 2018, p.840). By joining the Paris Agreement means that the country should agree with other nations in decreasing the pollution level, or in other words decreasing the number of manufacturers. Yet, Trump did not want that happen. So, in his utterance (15), he claims that by exiting the Paris Agreement will protect the United States from cutting the number of manufacturers and their economy will be safe.

In example (16), Trump also claimed that his action, which is suspending diplomatic relations with the Cuban government, is the right thing to do to protect Cuban people and prevent them from unfavorable things happening in the future. In fact, suspending the diplomatic relations, which is actually has been restored previously by Obama in late 2014, can be a bad idea since it can harm Cuba because the suspense can affect Cuba's various sectors. So it can be said what Trump has uttered has an illocutionary force of claiming as he claimed that suspending Cuba-US ties is a best decision to do.

Meanwhile, in example (17), Trump expresses the act of claiming by uttering that building walls in 
US-Mexico border works better in preventing illegal immigrants in crossing the US-Mexico border. In fact, building border wall needs a huge amount of fund and takes time in constructing the border wall. Moreover, the border wall's funding has taken part in the US' government shutdown earlier this year which resulted in many federal workers didn't receive any monthly pay (Gajanan, 2019, para.2) . So, it can be concluded that the utterance in the example (16) has an intention of claiming as the claim has not been proved right.

In stating the claims, Trump tends to utter what he think is right, although many people do not think the same as him. A theory from Habermas (as cited in Chilton, 2004) mentions that "the claim to 'rightness' partly means that the performing of speech acts are grounded in an implicit claim, on the part of the speaker, to inhabit a particular social or political role, and to possess a particular authority." (p. 44). So, Trump, from the examples of claiming, tries to imply the illocutionary force of claiming as someone who has authority or power in order that the claims can strengthen his utterance.

\section{Declaring}

According to Collins Online Dictionary, declare (n.d.) is to make clearly known; state or announce openly, formally. Leech (1983) adds that declare is making $\mathrm{P}$ (proposition) publicly known. There are three utterances found which have illocutionary force of declaring.

(18) Therefore, in order to fulfill my solemn duty to protect America and its citizens, the United States will withdraw from the Paris Climate Accord - (applause) - thank you, thank you - but begin negotiations to reenter either the Paris Accord or a really entirely new transaction on terms that are fair to the United States, its businesses, its workers, its people, its taxpayers. (PCA.DC.01)

(19) Therefore, effective immediately, I am cancelling the last administration's completely one sided deal with Cuba. (PUSTC.DC.02)

(20) So, we're going to confront the national security crisis on our southern border. (HCOSB.DC.03)
In the three speeches, examples (18), (19), and (20) are found having the illocutionary force of declaring. In example (18), Trump uttered to declare that the United States will withdraw from the Paris Agreement, as a defense of Trump's duty to protect America and put the US above other nations. Example (19) is uttered to declare that the United States, under Trump's presidency, is suspending the deal or diplomatic relation with Cuba under the condition that the relation only brought benefits to the higher ups government and military of Cuba instead of Cuban people. Example (20) is used to declare that the US is going to confront the national security and humanitarian crisis in order to stop illegal immigrants from crossing the US-Mexico border.

According to Searle (1976), declarative effects immediate changes in some current state of affairs. In this case for example in example (18) Trump brings changes from the United States joined the Paris Agreement in the past to US is withdrawing from the Paris Agreement. It applies the same in examples (19) and (20). In example (19), the United States and Cuba used to have the diplomatic relation, but the United States under Trump's presidency, is suspending the relation. Meanwhile, in example (20) implies that in the US-Mexico border there are old fences and walls, yet Trump thinks that because there is no concrete wall there are so many illegal immigrants crossing the border in order to come to the United States. So, Trump is going to stop the illegal immigrants coming to the United States by declaring that there is national security crisis so that the hearers believe the issue is happening.

\section{Denying}

Bach and Harnish (1979) states that deny is assert's negation, which means assert...not... (p. 42). Thus, it can be said that denying is assert but in negative sentences. The utterances which have illocutionary force of denying appear five times in the speeches.

(21) But we will not be silent in the face of communist oppression any longer. (PUSTC.DN.01)

(22) They don't have to be doing this. (HCOSB.DN.02) 
Those utterances have an indicating illocutionary device of 'not' which means a negation. In example (21), Trump asserts that the US is not going to be silent towards Cuba's communist oppression to their people any longer. The utterance of example (21) is based on the truth value from the previous statement in which Trump said that communism in Cuba has destroyed the nation. So, the United States is not going to be silent to the communist oppression and want to save the Cuban people.

Meanwhile, before the statement of example (22), Trump says that he had great respect to people who were fighting for their children whom had been killed by illegal immigrants in the US. Trump later referred to them as brave people. So, in utterance (22) Trump asserted that the parents did not have to present, attending the event where Trump delivered the speech, because they had suffered so much.

\section{Maintaining}

Bach and Harnish (1979) pointed out that when one maintains or avows something, one's expressed belief and intention are very strong (pp. 44-45). So, it means that the degree strength of maintaining is stronger than other acts. Fraser (1975) viewed that "maintain entails that the speaker has already once asserted the proposition." (p.191). There are four utterances found in the three speeches which have illocutionary force of maintaining.

(23) And I think the people of our country will be thrilled, and I think then the people of the world will be thrilled. But until we do that, we're out of the agreement. (PCA.MN.01)

(24) We have to. We have no choice. We have to. (PUSTC.MN.02)

(25) It's wrong. It's just a lie. It's all a lie. (HCOSB.MN.03)

In example (23), the intention that has been found is maintaining. It is because Trump keeps stating that the United States is out of the Paris Agreement, even though in the earlier sentences Trump has said the same sentence. Furthermore, in examples (24) and (25) there are no performative verbs found yet it has an intention of maintaining. Trump uses maintaining in examples (24) and (25) by saying again what he has said earlier or repeating what he says in order to assert the utterances he wants to highlight, for instance in the examples (24) and (25) he uses the same sentences twice. This usage of the same sentence can infer that the degree of strength of the utterance the speaker wants to convey is higher. Thus, it concludes that examples (23), (24), and (25) have the intention of maintaining because the utterance implies the higher degree of strength.

\section{Propounding}

According to Collins Online Dictionary, propound (n.d.) is to put forward for consideration; propose. Risselada (1990) gives an example of proposals let's. As Risselada (1990) indicates, "proposals resemble suggestions in that they are attempts, in a noncompulsary way, to get the addressee to undertake a particular of action or behavior. However, the content of a proposal, unlike that of a suggestion, does not exclusively concern the benefit of the addressee, but involves both the speaker and the addressee" (p.17). There is only one utterance found which have illocutionary force of propounding.

(26) So if the obstructionists want to get together with me, let's make them non-obstructionists. (PCA.PR.01)

In that context, Trump was suggesting an idea to the US government to make the obstructionists to be non-obstructionist if they want to work together with Trump by using imperative sentence. Obstructionist (n.d.), according to Collins Online Dictionary, means that anyone who obstructs progress; esp., a member of a legislative group who hinders the passage of legislation by various technical maneuvers. In other words, it means that Trump proposes by stating that he is willing to work with the obstructionists (people who have different views from Trump), under a condition that the obstructionists changed their views, or the same view as Trump. Thus, this concludes that example (26) has an illocutionary intention to propose.

\section{Saying}

According to Collins Online Dictionary, say (n.d.) is to express in words or to state positively, with assurance, or as an opinion. Total of seven 
utterances containing illocutionary force of saying are found.

(27) To the Cuban government, I say : Put an end to the abuse of dissidents. (PUSTC.SY.01)

\section{(28) They say walls don't work. (HCOSB.SY.05)}

In examples (27) and (28), the act of saying is expressed explicitly because performative verbs of 'say' can be found. On the example (27), Trump has an intention to say to the Cuban government, that is to put Cuban dissident's abuse an end because Trump assumed that there are some innocent people being abused by the Cuban government. Then in example (28), Trump uses the performative verb of saying to report that the Democrats party people stated that border walls do not work in preventing illegal immigrants cross the southern border. In conclusion, the performative verb 'say' shows that the utterance has the illocutionary force of saying.

\section{Stating}

According to Collins Online Dictionary, state (n.d.) is to set forth in words, esp. in a specific, definite, or formal way. Stating is the most used illocutionary force with 67 occurrences.

(29) Our embassy remains open in the hope that our countries can forge a much stronger and better path. America believes that free, independent, and sovereign nations are the best vehicle for human happiness, for health, for education, for safety, for everything. (PUSTC.ST.45)

(30) The probably easiest one to win is on declaring a national emergency, because we're declaring it for virtual invasion purposes: drugs, traffickers, and gangs. (HCOSB.ST.67)

In example (29), though there is no performative verb of 'state' but the utterance expresses an intention of stating. It can be seen that Trump is saying a proposition that the United States believed every independent nation deserves happiness, good health and education, and safety. This comes from the truth value from the previous sentence which said that the United States' embassy remained open because the United States is on the Cuban people's side, not the Cuban government. This act is placed upon on a belief that the United
States is a country that sees a free and independent nations leads to its own safety, happiness, and everything. So, the United States wants to keep helping the Cuban people even though the United States and Cuba has suspended their diplomatic relation. Therefore, the utterance has intention to deliver the information of the United States' belief of an independent nation.

Meanwhile in example (30), the illocutionary act of stating can be found. The utterance has been expressed by Trump to inform the hearer that the easiest win had been gained by Trump was on declaring the national emergency of security crisis on the Southern border. The truth value can be found on the next sentence that Trump was declaring the national emergency because of the invasions of drugs, traffickers, and gangs to the people of United States. All in all, the utterance in examples (29) and (30) can show the intention of stating information.

\section{CONCLUSION}

The present study finds out there are 152 utterances which contain assertive speech acts. Trump, in expressing utterances in his speeches, mostly used the act of stating with $44 \%$ occurrences, followed by the act of alleging with $(13,8 \%)$. The third commonly used is asserting $(11,8 \%)$ succeeded by the act of claiming $(10,5 \%)$. Meanwhile, other acts occur less than 5\%, for instance saying (4,6\%), affirming (3,2\%), avowing $(3,2 \%)$, denying (3,2\%), maintaining $(2,6 \%)$, declaring (1,9\%), and propounding occurs only $0,6 \%$. The act of averring, indicating, and submitting are not found in the speeches.

The three speeches actually has intention in declaring policies which has been changed by Trump, particularly withdrawing from the Paris Agreement, suspending diplomatic relation with Cuba, and announcing a national and humanitarian crisis on the southern border. This declaration has to be followed by statements which are able to support Trump's decision in changing the policies. All in all, the act of stating has been commonly used by Trump on his speeches because he wants the hearer to believe him that the policies he has made 
are the best things to do for the United States.

This research only concentrates on assertive speech acts in Trump's presidential speeches. Thus, a future research should add a comparison between the use of assertive speech acts in the speeches in order to know whether the assertive speech acts are significant to the speech or not. It also suggested that Trump's speeches which deal with other aspects such as health, economy, education, or etc should be added in order to compare the use of assertive speech acts in other significant sectors.

\section{REFERENCES}

Affirm. (n.d.). In Collins English Dictionary.

Retrieved from

https://www.collinsdictionary.com/dictionary /english/affirm

Akinwotu, S. A. (2013). A speech act analysis of the acceptance of nomination speeches of chief Obafemi Awolowo and Chief M.K.O. Abiola. English Linguistics Research, 2 (1), 43-51. http://dx.doi.org/10.5430/elr.v2n1p43

Alattar, R. A. S. (2014). A speech act analysis of American presidential speeches. Arts Journal, (110), 1-40. Retrieved from https://www.iasj.net/iasj?func=article\&aId=97 967

Allan, K. (1986). Linguistics meaning : Volume II. New York, N: Routledge.

Allan, K. (1998). Meaning and speech acts. Retrieved from http://users.monash.edu.au/ ${ }^{\sim}$ kallan/papers/Sp eechacts.html

Allege. (n.d.). In Collins English Dictionary.

Retrieved from https://www.collinsdictionary.com/dictionary /english/allege

Assert. (n.d.). In Collins English Dictionary.

Retrieved from https://www.collinsdictionary.com/dictionary /english/assert

Austin, J. L. (1962). How to do things with words. Oxford, UK: Oxford University Press.
Avow. (n.d.). In Collins English Dictionary.

Retrieved from https://www.collinsdictionary.com/dictionary /english/avow

Bach, K. (2006). Speech acts and pragmatics. In M. Devitt \& R. Hanley (Eds.), The Blackwell guide to the philosophy of language (pp. 147440). Oxford, UK: Blackwell Publishing.

Bach, K., \& Harnish, R. M. (1979). Linguistic communication and speech acts. Cambridge: MIT Press.

Chilton, P. (2004). Analysing political discourse : Theory and practice. London: Routledge.

Claim. (n.d.). In Collins English Dictionary.

Retrieved from https://www.collinsdictionary.com/dictionary /english/claim

Cohen, A. \& Krifka, M. (2014). Superlative quantifiers and meta-speech acts. Linguistics and Philosophy, 37 (1), 41-90. Retrieved from https://link.springer.com/article/10.1007/s109 88-014-9144-x

Declare. (n.d.). In Collins English Dictionary. Retrieved from https://www.collinsdictionary.com/dictionary /english/declare

Deny. (n.d.). In Collins English Dictionary.

Retrieved from

https://www.collinsdictionary.com/dictionary /english/deny

Euronews. (2019, February 6). Donald Trump calls for unity while repeating controversial policies in State of the Union address.

Euronews. Retrieved from https://www.euronews.com/2019/02/06/donal d-trump-calls-for-unity-while-repeatingcontroversial-policies-in-state-of-the-union

Fischer-Baum, R. \& Vitkovskaya, J. (2018, January

22). One year of Trump : How the administration changed American foreign policy. The Washington Post. Retrieved from https://www.washingtonpost.com/graphics/20 17/world/trump-shiftingalliances/?utm_term=.a4779b78bfea

Fraser, B. (1975). Hedged performatives. In P. Cole \& J. L. Morgan (Eds.), Syntax and Semantics 3: 
Speech acts (pp. 187-210). New York: Academy Press.

Gajanan, M. (2019, January 30). 'I'm Going to save every dollar I can.' Government workers are saving and looking for private industry jobs to prepare for another shutdown. Time.

Retrieved from https://time.com/5515372/governmentshutdown-workers-trump/

Hardjanto, T. \& Mazia, N. (2018). "We believe in democracy...": Epistemic modality in Justin Trudeau's political speeches. Jurnal Humaniora, 31 (2). Retrieved from https://jurnal.ugm.ac.id/jurnalhumaniora/article/view/44948/0

Hashim, S. S. M. (2015). Speech acts in political dpeeches. Journal of Modern Education Review, 5 (7), 699-706. Retrieved from https://pdfs.semanticscholar.org/0b7a/d998f72 dd5925b3cf3a7c2d0d2302a7b0f00.pdf

Khoirunnisa, A. (2015). Illocutionary acts found in Soekarno's speech in the 1955 Asian African conference (Unpublished undergraduate Thesis), Universitas Gadjah Mada, Yogyakarta, Indonesia.

Lazuka, A. (2006). Communicative intention in George W. Bush's presidential speeches and statements 11 September 2001 to 11 September 2003. Discourse and Society, 17 (3), 299-330.

Leech, G. (1983). Principle of pragmatics. London/New York: Longman.

Mey, L. (2001). Pragmatics: An Introduction. Oxford: Blackwell Publishing.

Mufiah, N. S. \& Rahman, M. Y. N. (2018). Speech acts analysis of Donald Trump's speech. Professional Journal of English Education, 1 (2). Retrieved from https://journal.ikipsiliwangi.ac.id/index. php/project/article/download/461/67

Obstructionist. (n.d.). In Collins English Dictionary. Retrieved from https://www.collinsdictionary.com/dictionary /english/obstructionist
Propound. (n.d.). In Collins English Dictionary. Retrieved from https://www.collinsdictionary.com/dictionary /english/propound

Risselada, R. (1990). Illocutionary function and functional illocution. Amsterdam: Working Papers in Functional Grammar 34.

Say. (n.d.). In Collins English Dictionary. Retrieved from https://www.collinsdictionary.com/dictionary /english/say

Searle J. R. \& Vanderveken D. (1985). Foundations of illocutionary logic. Cambridge: Cambridge University Press.

Searle, J. R. (1976). A classification of illocutionary acts. Language in Society, 5(1), 1-23.

State. (n.d.). In Collins English Dictionary. Retrieved from https://www.collinsdictionary.com/dictionary /english/state

Urpelainen, J. \& Van de Graff, T. (2018). United States non-cooperation and the Paris agreement. Climate Policy, 18 (7), 839-851. https://doi.org/10.1080/14693062.2017.140684 3

Very. (n.d.). In Collins English Dictionary. Retrieved from https://www.collinsdictionary.com/dictionary /english/very

White House. (2017, June 1). Statement by President Trump on the Paris Climate Accord. Retrieved from https://www.whitehouse.gov/briefingsstatements/statement-president-trump-parisclimate-accord/

White House. (2017, June 16). Remarks by President Trump on the Policy of the United States Towards Cuba. Retrieved from https://www.whitehouse.gov/briefingsstatements/remarks-president-trump-policyunited-states-towards-cuba/ 
White House. (2019, February 15). Remarks by

President Trump on the National Security and Humanitarian Crisis on our Southern Border. Retrieved from

https://www.whitehouse.gov/briefingsstatements/remarks-president-trumpnational-security-humanitarian-crisissouthern-border/
Zhou-Castro, H. (2019, March 7). Trump's US-

Mexico border policies under fire in Congress. Al Jazeera. Retrieved from https://www.aljazeera.com/news/2019/03/tru mps-us-mexico-border-policies-fire-congress190307060835247.html 